\title{
New Curculioninae (Coleoptera: Curculionidae) in Dominican amber
}

\author{
George Poinar, Jr. and Andrei A. Legalov
}

\begin{abstract}
A new genus and four new species of Curculioninae are described from Dominican amber. Neosibinia gen. nov. differs from the extant genera Tychius and Sibinia by the tibiae lacking a mucro and uncus, the elongate pronotum distinctly narrower than the elytral humeri and the sharp bend in the rostrum. Derelomus thalioculus sp. nov. differs from other Derelomus species by the body covering of fine, dense setae. Anthonomus cruraluma sp. nov. is similar to the extant $A$. filicornis but differs by the tibiae with mucro, elongate body, shorter rostrum, and the smaller body size. Anthonomus browni sp. nov. is distinguished from the extant $A$. sulcipygus by its narrow elongate body, femora with minute distal tooth and shorter and thicker rostrum. These new taxa further demonstrate the diversity of weevil fauna in Dominican amber.
\end{abstract}

George Poinar, Jr. Department of Integrative Biology, Oregon State University, Corvallis, Oregon 97331, USA. poinarg@science.oregonstate.edu

Andrei A. Legalov. Laboratory of Phylogeny and Faunogenesis, Institute of Systematics and Ecology of Animals, Siberian Branch, Russian Academy of Sciences, Frunze street, 11, Novosibirsk 630091, Russia. fossilweevils@gmail.com

Keywords: Derelimini; Anthonomini; Tychiini; new genus, new species; Dominican amber

\section{INTRODUCTION}

Weevils of the subfamily Curculioninae are diverse with respect to morphology and physiology. Recent studies by the authors have shown that the Dominican amber weevil fauna is represented by 73 species from 32 genera in the families Belidae, Brentidae and Curculionidae (Poinar, 2009; Poinar and Brown, 2011; Poinar et al., 2013; Poinar and
Legalov, 2014a, 2014b, 2014c, 2014d, 2015a, 2015b 2015c, 2015d).

Dating of Dominican amber is controversial with the latest purported age of 20-15 Ma based on foraminifera (Iturralde-Vinent and MacPhee, 1996) and the earliest of 45-30 Ma based on coccoliths (Cêpek in Schlee, 1990). In addition, Dominican amber is secondarily deposited in sedimentary rocks, which makes a definite age determination

http://zoobank.org/4BDD1B2E-9F26-4148-BD83-6EC570003701

PE Article Number: 18.1.13A

Copyright: Palaeontological Association March 2015

Submission: 26 September 2014. Acceptance: 25 February 2015

Poinar, George, Jr. and Legalov, Andrei A. 2015. New Curculioninae (Coleoptera: Curculionidae) in Dominican amber. Palaeontologia Electronica 18.1.13A: 1-15.

palaeo-electronica.org/content/2015/1101-new-curculioninae 
difficult (Poinar and Mastalerz, 2000). A range of ages for Dominican amber is possible as the amber is associated with turbiditic sandstones of the Upper Eocene to Lower Miocene Mamey Group (Draper et al., 1994). Dominican amber was produced by the leguminous tree, Hymenaea protera Poinar (Poinar, 1991) and a re-construction of the Dominican amber forest based on amber fossils indicated that the environment was similar to that of a present day tropical moist forest (Poinar and Poinar, 1999).

The present study describes representatives of Curculioninae from Dominican amber, including a new species of Derelomus Schoenherr, 1825 in the tribe Derelomini, two new species of Anthonomus Germar, 1817 in the tribe Anthonomini and a new genus in the tribe Tychiini.

\section{MATERIALS AND METHODS}

The specimens were obtained from amber mines in the Cordillera Septentrional of the Dominican Republic. Most types are deposited in the Poinar amber collection maintained at Oregon State University (PACO, Corvallis, OR, USA). One type is deposited in the American Museum of Natural History (AMNH, New York, NY, USA) collection.

Descriptions and photographs were produced by the authors using a Nikon SMZ-10 steroscopic microscope and Zeiss, Stemi-2000-C. Helicon Focus Pro X64 was used to stack photos for better clarity and depth of field. All measurements were made using an ocular micrometer.

\section{SYSTEMATIC PALAEONTOLOGY}

Family CURCULIONIDAE Schoenherr, 1825

Subfamily CURCULIONINAE Schoenherr, 1825

Tribe DERELOMINI Lacordaire, 1866

Genus Derelomus Schoenherr, 1825

Derelomus thalioculus sp. nov.

Figure 1, Figure 2

\section{zoobank.org/136AD4A5-4DCD-4080-BAE8-8D86E498E333}

Holotype. Deposited in the PACO (accession \# C82).

Description. Length body, $2.4 \mathrm{~mm}$; length rostrum, $0.5 \mathrm{~mm}$. Body reddish-brown, appearing glabrous but actually with a covering of fine, dense setae. Rostrum elongate, equal in length to pronotum, 4.6 times longer than wide in the middle, weakly curved, without carinae, finely punctate; antennal scrobes lateral and directed toward lower edge of the eyes; forehead wide, flattened, punctate; eyes large, rounded, distinctly convex, diameter slighter greater than rostrum at base; vertex weakly convex and finely punctate; temples elongate, equal in length to eye; antennae inserted in middle of rostrum, elongate, almost reaching apex of pronotum; scape elongate, 8.0 times longer than wide; funicle with first to seventh antennomeres conical; first antennomere 2.1 times longer than wide; second antennomere 1.3 times longer than wide, 0.3 times as long and 0.4 times as narrow as first antennomere; third to fifth antennomeres subequal in length; third antennomere equal in length and width, 1.3 times as wide as second antennomere; fourth antennomere 0.8 times longer than wide, 1.2 times as wide as third antennomere; fifth antennomere equal to fourth antennomere; sixth antennomere 0.9 times longer than wide, 1.4 times as long and 1.3 times as wide as fifth antennomere; seventh antennomere 0.7 times longer than width, 1.3 times as wide as sixth antennomere; club compact, 1.4 times longer than wide, 0.4 times as long as funicle.

Pronotum almost conical; 1.6 times longer than wide at apex, of equal length and width in middle, 0.9 times longer than wide at base, with lateral carinae; disk flattened, densely and finely punctate; scutellum trapezoidal.

Elytra elongate and distinctly flattened, 1.7 times longer than wide at base, 1.6 times longer than wide in middle, 2.4 times longer than wide at apical fourth, 2.4 times as long as pronotum; greatest width behind middle, humeri weakly convex; striae regular and thin; strial punctures small, oval, dense; elytral intervals flattened, wide, 4.0-5.0 times as long as striae; apices of elytra not rounded; pygidium concealed.

Thorax punctate; precoxal portion of prosternum elongate, 2.3 times as long as procoxal cavities, 14.0 times as long as postcoxal portion; procoxal cavities contiguous; mesocoxal cavities widely separated, metepisternum narrow, 3.7 times longer than wide in middle.

Abdomen weakly convex ventrally; first and second ventrites elongate, equal in length; third and fourth ventrites short, equal in length; third ventrite 0.5 times as long as second ventrite; fifth ventrite elongate, 1.3 times as long as fourth ventrite.

Legs long; pro- and mesocoxae round; metacoxae transverse; femora weakly clavate, without teeth; trochanters obconical; metafemora 3.2 times longer than wide; tibiae with very small, blunt mucro; protibia almost straight; meso- and metatibiae slightly curved; metatibiae 3.8 times longer than wide in middle; tarsi long; first to third tarsomeres conical; fifth elongate; tarsomeres with pulvilli on underside; tarsal claws free, large, clearly diverg- 


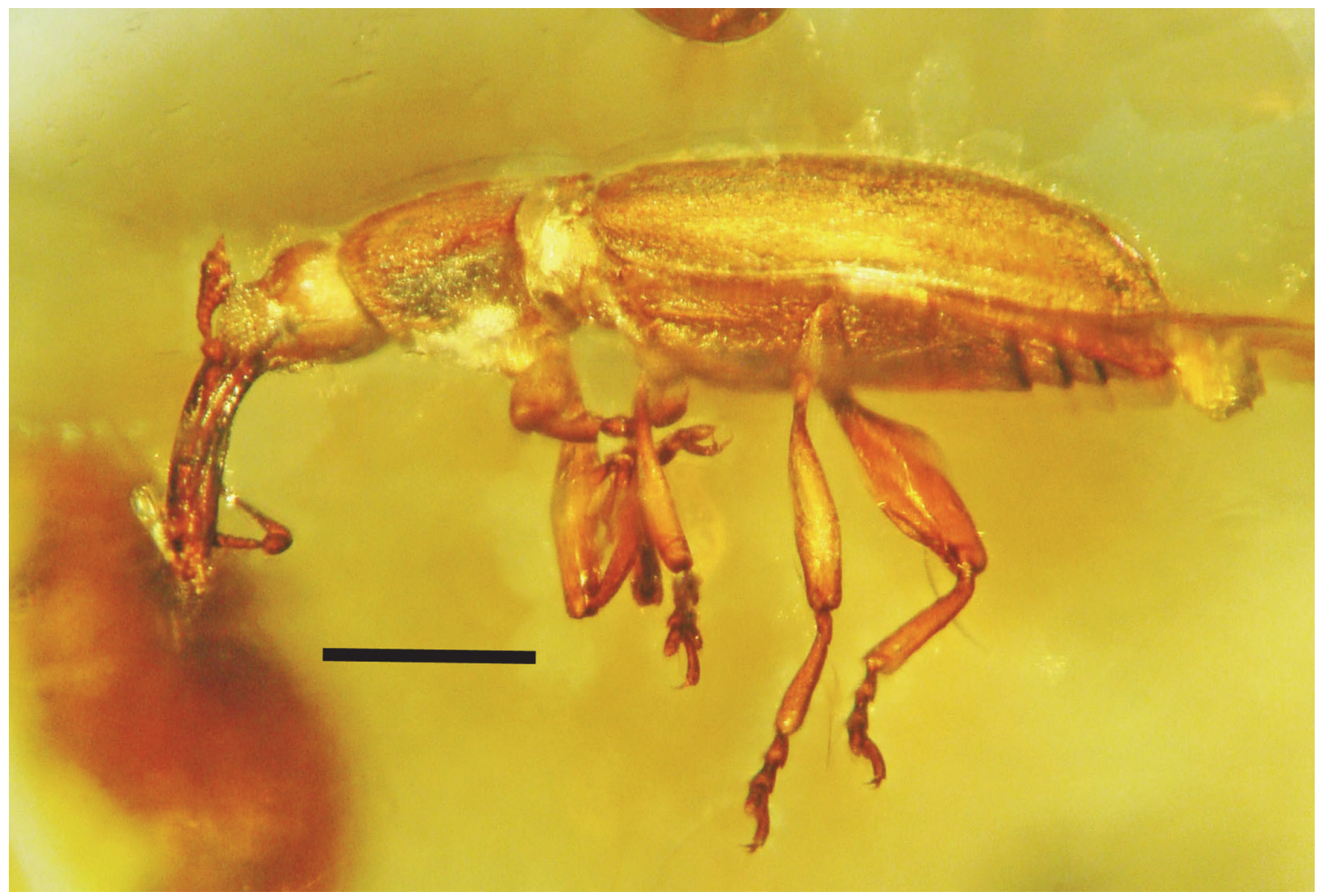

FIGURE 1. Lateral view of Derelomus thalioculus sp. nov. in Dominican amber. Bar equals $0.550 \mathrm{~mm}$.

ing, with basal teeth; metatarsus: first tarsomere 1.7 times longer than wide at apex; second tarsomere 1.5 times longer than wide at apex; third tarsomere bilobed, 0.8 times longer than wide at apex; fifth tarsomere 5.0 times longer than wide at apex, 2.0 times as long as third tarsomere.

Type Locality. Amber mine in the Cordillera Septentrional of the northern portion of the Dominican Republic.

Etymology. The specific epithet is from the Latin "thalus" = dome and the Latin "oculus" = eye in regards the convex eyes.

Remarks. The pronotum with lateral carinae, concealed pygidium, antennal scrobes directed to the eye, short precoxal portion of the prosternum and convex eyes are features of the genus Derelomus of the tribe Derelomini. The covering of fine, dense setae separates this species from other members of the genus whose bodies are all glabrous.

Tribe ANTHONOMINI Thomson, 1859

Genus Anthonomus Germar, 1817

Subgenus Anthomorphus Weise, 1883
Anthonomus (Anthomorphus) cruraluma sp. nov.

Figure 3, Figure 4, Figure 5

zoobank.org/824962CC-EB6E-4D3C-87BE-ECF658592432

Holotype. Female; deposited in the PACO (accession \# C-125).

Paratype. Male; deposited in the AMNH (accession \# AMNH DR-8-414).

Since many diagnostic features are obscured in the male specimen, we have designated the female as holotype.

Description. Length body, 2.0-2.2 mm; length rostrum, 0.8-0.9 mm. Body reddish brown, with dense covering of light, recumbent, setiform scales.

Rostrum elongate, 1.3 (male) - 1.8 (female) times as long as pronotum, 7.5 (male) - 9.6 (female) times longer than wide at apex, 6.4 (male) - 8.4 (female) times longer than wide in middle, 6.0 (male) - 7.4 (female) times longer than wide at base, distinctly curved, without carinae, finely and slightly punctate; antennal scrobes lateral and directed toward middle of eye; forehead narrow, flattened, punctate; eyes large, rounded, distinctly convex, diameter much greater than rostrum at base; vertex weakly flattened, punctate; temples 


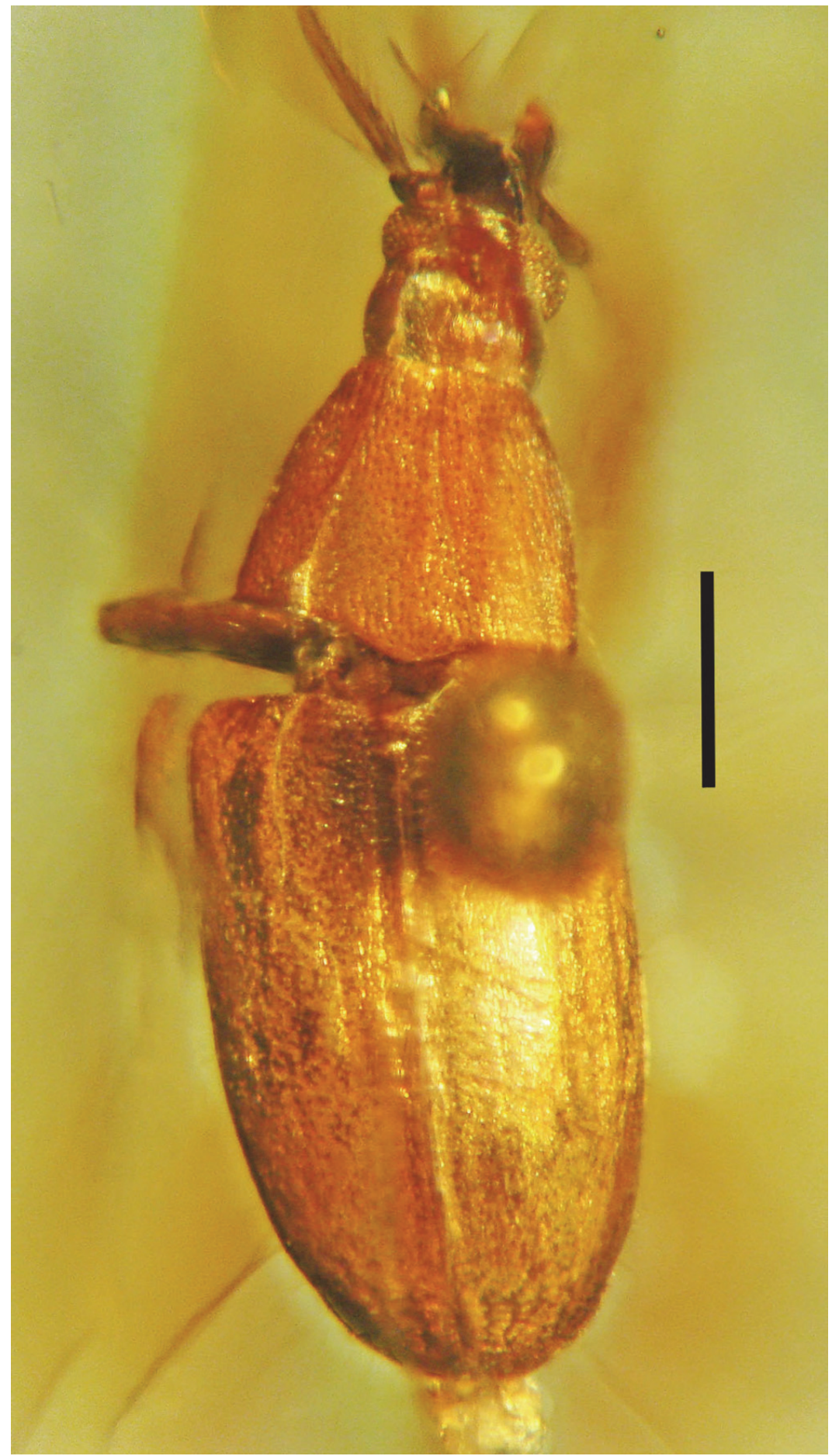

FIGURE 2. Dorsal view of Derelomus thalioculus sp. nov. in Dominican amber. Bar equals 0. 440 mm.

quite short, 0.4 times as long as eye, punctate; antennae inserted in apical third of rostrum, elongate, almost reaching base of pronotum; scape elongate, 15.2 times longer than wide, 1.2 times as long as funicle length; funicle with first to seventh antennomeres conical-elongate; first antennomere
2.7 times longer than wide, 0.2 times as long as and 1.2 times as wide as scape; second to sixth antennomeres almost of equal width; second antennomere 3.0 times longer than wide, 0.8 times as long as first antennomere; third antennomere 2.0 times longer than wide, 0.7 times as long as 


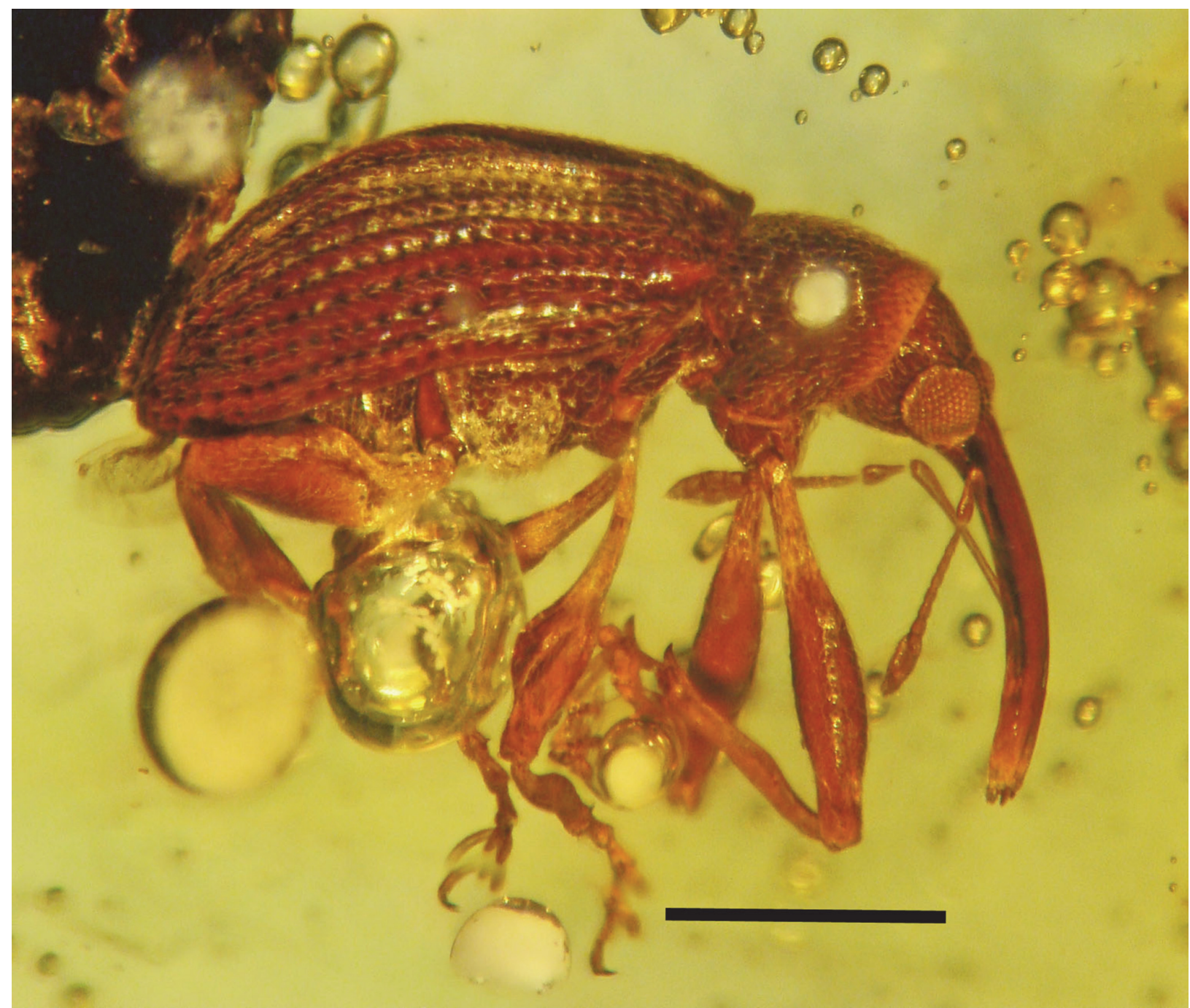

FIGURE 3. Lateral view of Holotype Anthonomus cruraluma sp. nov. in Dominican amber. Bar equals $0.730 \mathrm{~mm}$.

second antennomere; fourth antennomere equal to third antennomere; fifth antennomere 1.5 times longer than wide, 0.8 times as long as fourth antennomere; sixth antennomere equal to fifth antennomere; seventh antennomere 1.6 times longer than wide, 1.3 times as long as and 1.3 times as wide as sixth antennomere; club compact, 2.4 times longer than wide, 0.4 times as long as funicle; first club almost of equal length and width, equal to length and 1.6 times as wide as seventh antennomere; second club equal to first club article; third club article distinctly acuminate at apex.

Pronotum bell shaped; 1.8 times longer than wide at apex, 0.94 times longer than wide in middle, 0.91 times longer than wide at base; disk weakly convex, weakly narrowed at apex and base, densely punctate; scutellum trapezoidal, convex.

Elytra elongate and distinctly convex, 1.6 times longer than wide at base, 1.5 times longer than wide in middle, 2.2 times longer than wide at apical fourth, 2.1-2.4 times as long as pronotum, without transverse basal patch of scales; greatest width behind the middle, humeri distinctly convex; striae regularly and distinctly punctate; strial punctures oval, quite dense; elytral intervals convex, 1.2-2.0 times as long as striae; apex of elytra separately acuminate.

Thorax punctate; procoxal cavities more or less equidistant from anterior and posterior margin of prosternum; precoxal portion 0.4 times as long as procoxal cavity length; procoxal cavities contiguous; mesocoxal cavities widely separated, metepisternum narrow, 5.0 times longer than wide in middle.

Abdomen convex ventrally; ventrites almost homogeneous; first and second ventrites equal in length; third and fourth ventrites slightly shorter than previous; fifth ventrite elongate, 1.4 times as long as 


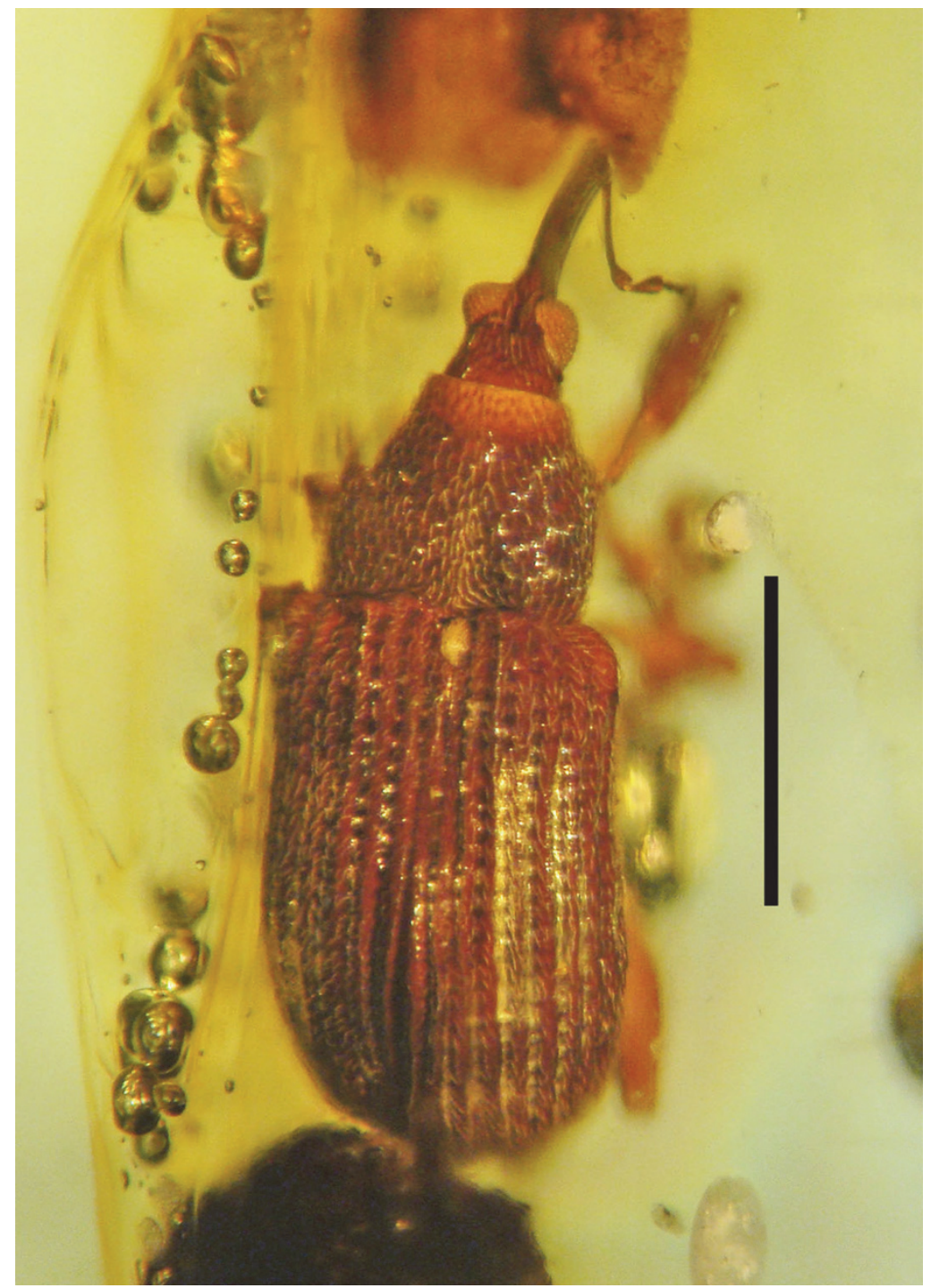

FIGURE 4. Dorsal view of Holotype Anthonomus cruraluma sp. nov. in Dominican amber. Bar equals $0.780 \mathrm{~mm}$.

fourth ventrite; fifth ventrite subquadrately emarginate of male; pygidium sulcate; pygidial channel broad and deep.

Legs long; pro- and mesocoxae conical; metacoxae transverse; femora weakly clavate; trochanters obconical; profemora bidentate, first tooth large and second tooth small; meso- and metafemora toothed; profemora 3.9-5.4 times longer than wide; mesofemora 6.1 times longer than wide; metafemora 4.6-4.8 times longer than wide; tibiae with weak prominence on ventral margin; protibia almost straight, with large mucro; meso- and metatibiae slightly curved, with mucro; protibiae 7.0-7.8 times longer than wide in middle; metatibiae 5.5 times longer than wide in middle, without ventral fringe of setiform scales; tarsi long; first to third tarsomeres conical; fifth elongate; tarsomeres with pulvilli on underside; tarsal claws free, large, with basal teeth.

Type Locality. Amber mine in the Cordillera Septentrional of the northern portion of the Dominican Republic.

Etymology. The specific epithet is from the Latin "luma" = thorne and the Latin "cruris" = leg in regards to the large mucro on the fore tibia.

Comparison. The new species is similar to Anthonomus filicornis Hustache, 1929 from Guadeloupe and South America but differs by the tibiae with mucro, body elongate, rostrum shorter, and the smaller body size.

Remarks. Placement of Anthonomus cruraluma sp. nov. (AMNH DR-8-414 and C-125) in the tribe Anthonomini was based on the antennal scrobes directed toward the eyes, the short prosternum, 


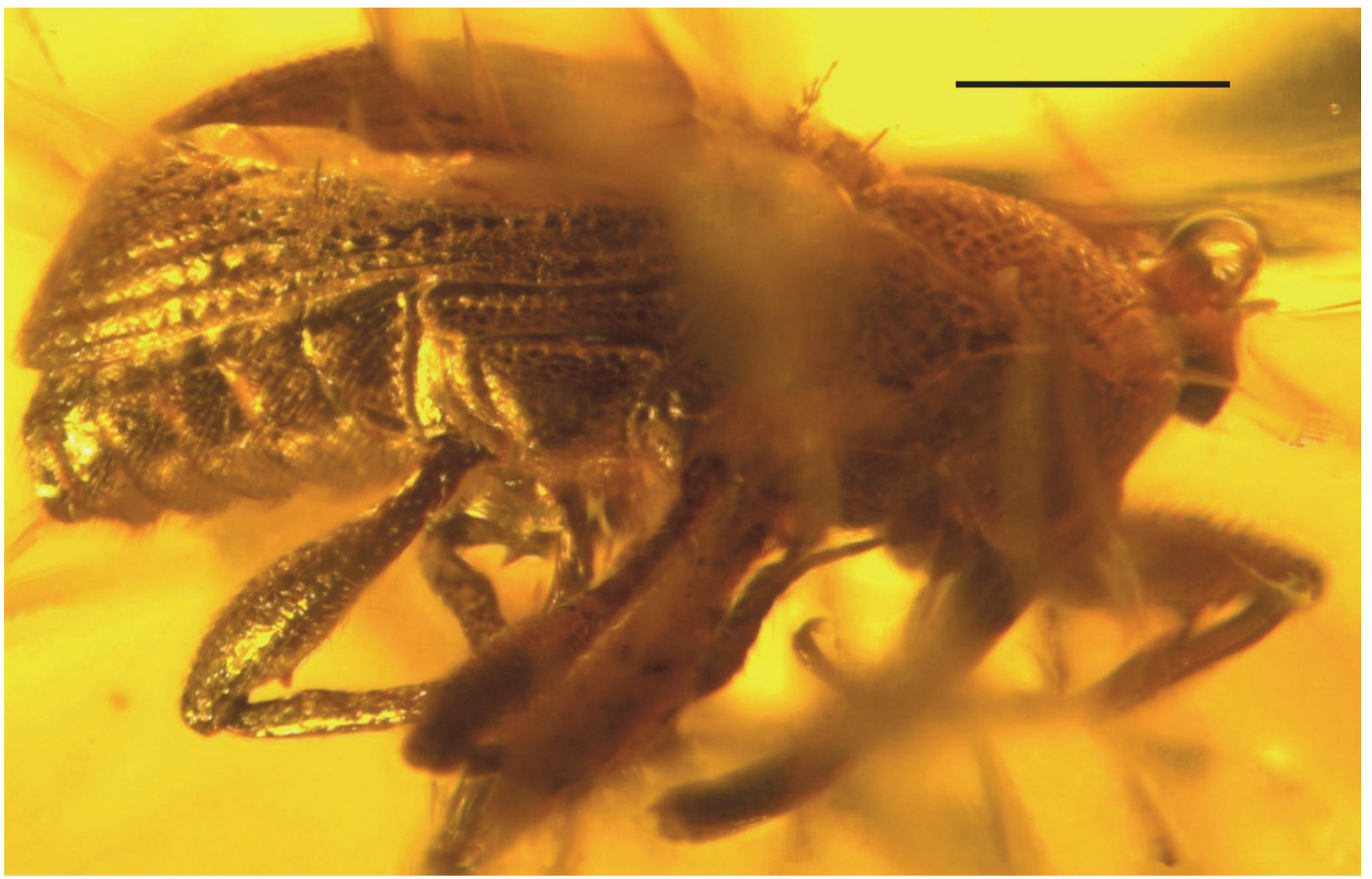

FIGURE 5. Lateral view of Paratype Anthonomus cruraluma sp. nov. in Dominican amber. Bar equals $0.500 \mathrm{~mm}$.

convex eyes, and the nature of the scutellum. Placement of this species in the genus Anthonomus is based on the tarsal claws with basal teeth, contiguous procoxae, widely separated mesocoxae, slender rostrum, longer than pronotum along dorsal midline, 7-articled antennal funicle, bidentate femora lateral antennal scrobes directed toward the middle of the eye, large eyes with the diameter much greater than the rostrum at base, elytra without a transverse basal patch of scales and straight protibia. The new species belongs to the subgenus Anthomorphus (Clark and Burke, 1987) based on the fifth ventrite subquadrately emarginate and pygidium sulcate.

Anthonomus (Anthomorphus) browni sp. nov. Figure 6, Figure 7

\section{zoobank.org/6D216399-D257-4A24-BB38-445A2D8DB5A5}

Holotype. Deposited in the PACO (accession \# C20).

Description. Length body, $3.0 \mathrm{~mm}$; length rostrum, $1.3 \mathrm{~mm}$.

Body elongate, reddish-brown, with dense, light setiform scales. Scape, flagellum, base of femora, tibiae, and basal portions of tarsi yellow.

Rostrum elongate, 1.6 times as long as pronotum, 7.5 times longer than wide at apex, 9.0 times lon- ger than wide in middle and at base, weakly curved, without carinae, finely punctate; antennal scrobes lateral and directed toward and reaching near middle of eye; forehead narrow, flattened, punctate; eyes large, distinctly convex, rounded, diameter slightly greater than rostrum at base; vertex weakly convex, punctate; temples quite long, equal in length to eye, punctate; antennae inserted near middle of rostrum, elongate, almost reaching base of pronotum; scape elongate, 8.0 times longer than wide, 0.8 times as long as funicle length; first to seventh antennomeres conical-elongate; first antennomere 3.0 times longer than wide, 0.5 times as long as and 1.3 times as wide as scape; second and third antennomeres almost equal in width; second antennomere 2.0 times longer than wide, 0.3 times as long and 0.5 times as wide as first antennomere; third to sixth antennomeres almost equal in width; third antennomere 0.8 times as wide as second antennomere; fourth antennomere 2.0 times longer than wide, 0.8 times as long as width of third antennomere; fifth antennomere 1.8 times longer than wide, 0.9 times as long as fourth antennomere; sixth antennomere equal to fifth antennomere; seventh antennomere 1.3 times longer than wide, 1.1 times as long and 1.5 times 


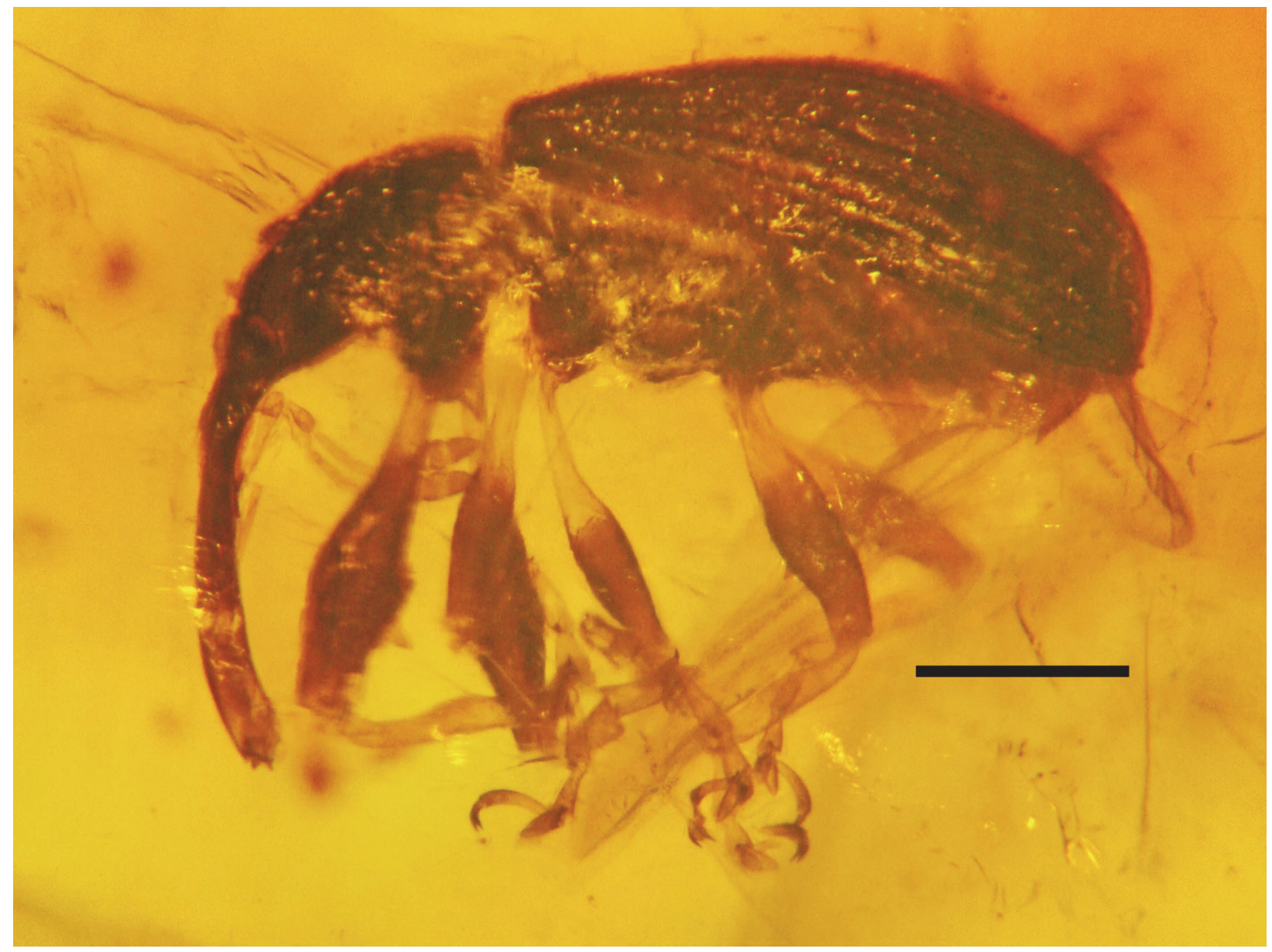

FIGURE 6. Lateral view of Anthonomus browni sp. nov. in Dominican amber. Bar equals $0.630 \mathrm{~mm}$.

as wide as sixth antennomere; club compact, elongate, 5.0 times longer than wide, 0.6 times as long as funicle; first club 1.8 times longer than wide, 1.8 times as long and 1.3 times as wide as seventh antennomere; second club 1.4 times longer than wide, equal in length and 1.3 times as wide as first club article; third club article 3.1 times longer than wide at base, 1.6 times as long as and 0.7 times as wide as second club article, acuminate at apex.

Pronotum bell-shaped, 2.2 times longer than wide at apex, 0.8 times longer than wide in middle and at base; disk densely punctate, weakly convex, narrowed at apex; scutellum trapezoidal, convex.

Elytra elongate and convex, 1.9 times longer than wide at base, 1.8 times longer than wide in middle, 2.0 times longer than wide at apical fourth, 3.5 times as long as pronotum; greatest width behind middle; humeri weakly convex; elytral striae regular and deep; strial punctures oval, dense; elytral intervals convex, wide, 2.5-3.0 times as long as striae; apex of elytra separately acuminate.
Thorax punctate; precoxal portion 0.5 times as long as procoxal cavity length; procoxal cavities more or less equidistant from anterior and posterior margin of prosternum; procoxal cavities slightly separated; mesocoxal cavities separated; metepisternum narrow.

Abdomen convex ventrally; ventrites almost homogeneous; first and second ventrites equal in length; third ventrite 0.7 times as long as second ventrite; third and fourth ventrites equal in length; fifth ventrite 1.2 times as long as fourth ventrite; fifth ventrite subquadrately emarginate; pygidium sulcate.

Legs long; pro- and mesocoxae conical; metacoxae transverse, 0.3 times as long as metasternum; trochanters obconical; femora distinctly clavate, with a minute distal tooth; profemora 3.7 times longer than wide; mesofemora 4.7 times longer than wide; metafemora 3.9 times longer than wide; protibia weakly curved, with large mucro; meso- and metatibiae slightly curved, with mucro; protibiae 5.9 times longer than wide in mid- 


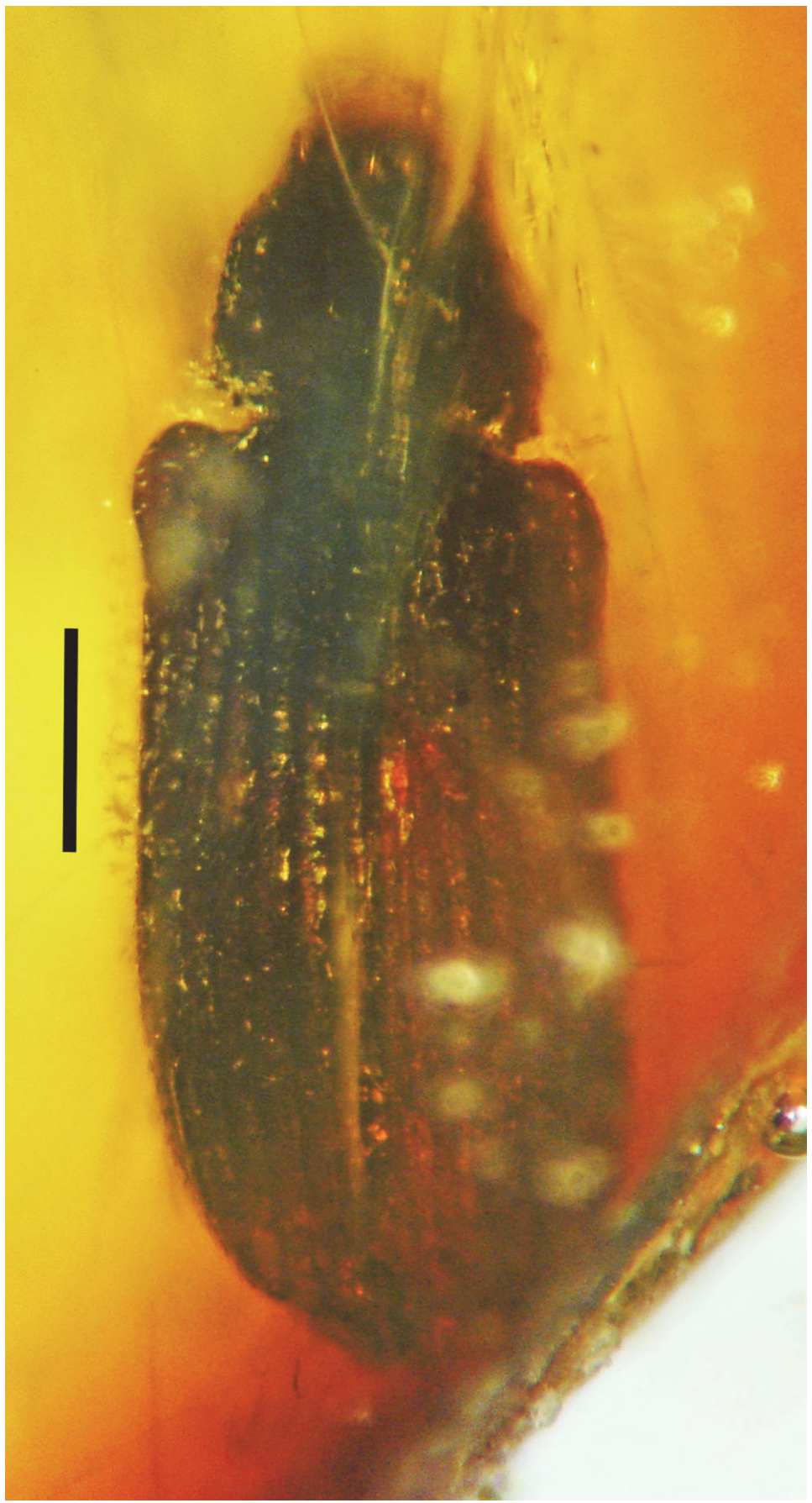

FIGURE 7. Dorsal view of Anthonomus browni sp. nov. in Dominican amber. Bar equals $0.550 \mathrm{~mm}$.

dle; metatibiae 5.6 times longer than wide in middle; tarsi long; first to third tarsomeres conical; fifth elongate; tarsomeres with pulvilli on underside; tarsal claws free, very small, without basal teeth.

Type Locality. Amber mine in the Cordillera Septentrional of the northern portion of the Dominican Republic.

Etymology. The species epithet is named in honor of A.E. Brown.
Comparison. The new species differs from Palaearctic $A$. phyllocola (Herbst, 1795) by its tarsal claws lacking basal teeth by the narrow elongate body, curved rostrum and clavate profemora. It differs from other Anthomorphus species by the tarsal claws lacking basal teeth. It is distinguished from A. sulcipygus Champion, 1903 of Central and South America by the narrow elongate body, fem- 
ora with minute distal tooth and shorter and thicker rostrum.

Remarks. Placement of this species in the genus Anthonomus is based on the contiguous procoxae, widely separated mesocoxae, slender rostrum longer than pronotum along dorsal midline, 7-articled antennal funicle, bidentate femora, lateral scrobes directed toward and reaching near middle of eye, large eyes with the diameter much greater than the rostrum at base, elytra without a transverse basal patch of scales and straight protibia. This new species belongs to the subgenus Anthomorphus (Clark and Burke, 1987) based on the sulcate pygidium and subquadrately emarginated fifth ventrite.

\section{Tribe TYCHIINI Thomson, 1859} Neosibinia gen. nov.

\section{zoobank.org/A9A7071C-9814-4345-8E0A-5405B9B74AE6}

Type Species. Neosibinia lepidosoma sp. nov. Diagnosis. Body with wide, densely placed scales, and some semi-erect narrow scales; head not constricted behind eyes; rostrum quite long, distinctly curved, especially in the middle; antennal scrobes lateral and directed toward base of rostrum; forehead narrow, flattened; eyes large, rounded, weakly convex; vertex weakly flattened, punctate; temples long, slightly larger than the eyes, punctate; antennae inserted beyond middle of rostrum, elongate, almost reaching base of pronotum; funicle with first to sixth antennomeres conical; club compact, elongate; pronotum elongate and bellshaped; disk weakly convex, slightly narrowed at apex and base, densely punctate; scutellum wide trapezoidal; elytra elongate and weakly convex; greatest width behind the middle; humeri weakly convex; striae regular and distinct; ninth elytral striae short and connate with tenth striae; pygydium covered by elytra; procoxal cavities more or less equidistant from anterior and posterior margin of prosternum; procoxal cavities separated; suture between second and third ventrites markedly extended posteriorly towards lateral margins between third and fourth ventrites; legs long; femora weakly clavate, without teeth; apex of tibia without mucro and uncus; tarsal claws connate at base, large, with basal teeth.

Etymology. The generic epithet is from the Greek "vÉos" = new and the genus "Sibinia".

Comparison. The new genus differs from the genera Tychius Germar, 1817 and Sibinia Germar, 1817 by the tibiae lacking a mucro and uncus, the elongate pronotum distinctly narrower than the elytral humeri and the sharp bend in the rostrum.

Remarks. The abdomen with the suture between the second and third ventrites markedly extended posteriorly towards the lateral margins of the third and fourth ventrites places the genus in the tribe Tychiini.

Neosibinia lepidosoma sp. nov.

Figure 8, Figure 9

zoobank.org/86D3530E-DE80-443A-A1C7-8C15DC9B1341

Holotype. Deposited in the PACO (accession \# C134).

Description. Length body, $2.2 \mathrm{~mm}$; length rostrum, $0.4 \mathrm{~mm}$.

Body brown, covered with reclining to erect scales. Rostrum 0.8 times as long as pronotum, 5.8 times longer than wide at apex, 3.9 times longer than wide in middle, 3.4 times longer than wide at base, without carinae, punctate; forehead 0.5 times as wide as eye width, punctate; diameter of eye slightly greater than rostrum at base; scape elongate, 6.0 times longer than wide, 1.1 times as long as funicle length; first antennomere 1.3 times longer than wide, 0.3 times as long as and 1.5 times as wide as scape; club 4.3 times longer than wide, equal in length to funicle.

Pronotum 1.6 times longer than wide at apex, 1.1 times longer than wide in middle, 1.2 times longer than wide at base. Elytra 1.6 times longer than wide at base, 1.4 times longer than wide in middle, 1.7 times longer than wide at apical fourth, 2.2 times as long as pronotum; strial punctures oval, large and dense; elytral intervals weakly convex, quite wide, 2.0-3.5 times as long as striae.

Thorax punctate; procoxal cavities more or less equidistant from anterior and posterior margin of prosternum; precoxal portion 0.4 times as long as procoxal cavity length; mesocoxal cavities widely separated, metepisternum narrow, 5.7 times longer than wide in middle.

Abdomen convex ventrally; first ventrites longer than second ventrite; third and fourth ventrites almost equal in length; fifth ventrite elongate. Proand mesocoxae conical; metacoxae transverse; trochanters obconical; profemora 4.5 times longer than wide; metafemora 2.8 times longer than wide; protibia slightly curved; metatibiae 4.6 times longer than wide in middle; tarsi long; first to third tarsomeres conical; fifth elongate; tarsomeres with pulvilli on underside.

Type Locality. Amber mine in the Cordillera Septentrional of the northern portion of the Dominican Republic.

Etymology. The specific epithet is from the Latin "lepis" = scale and the Latin "soma" = body in reference to the scales covering the body. 


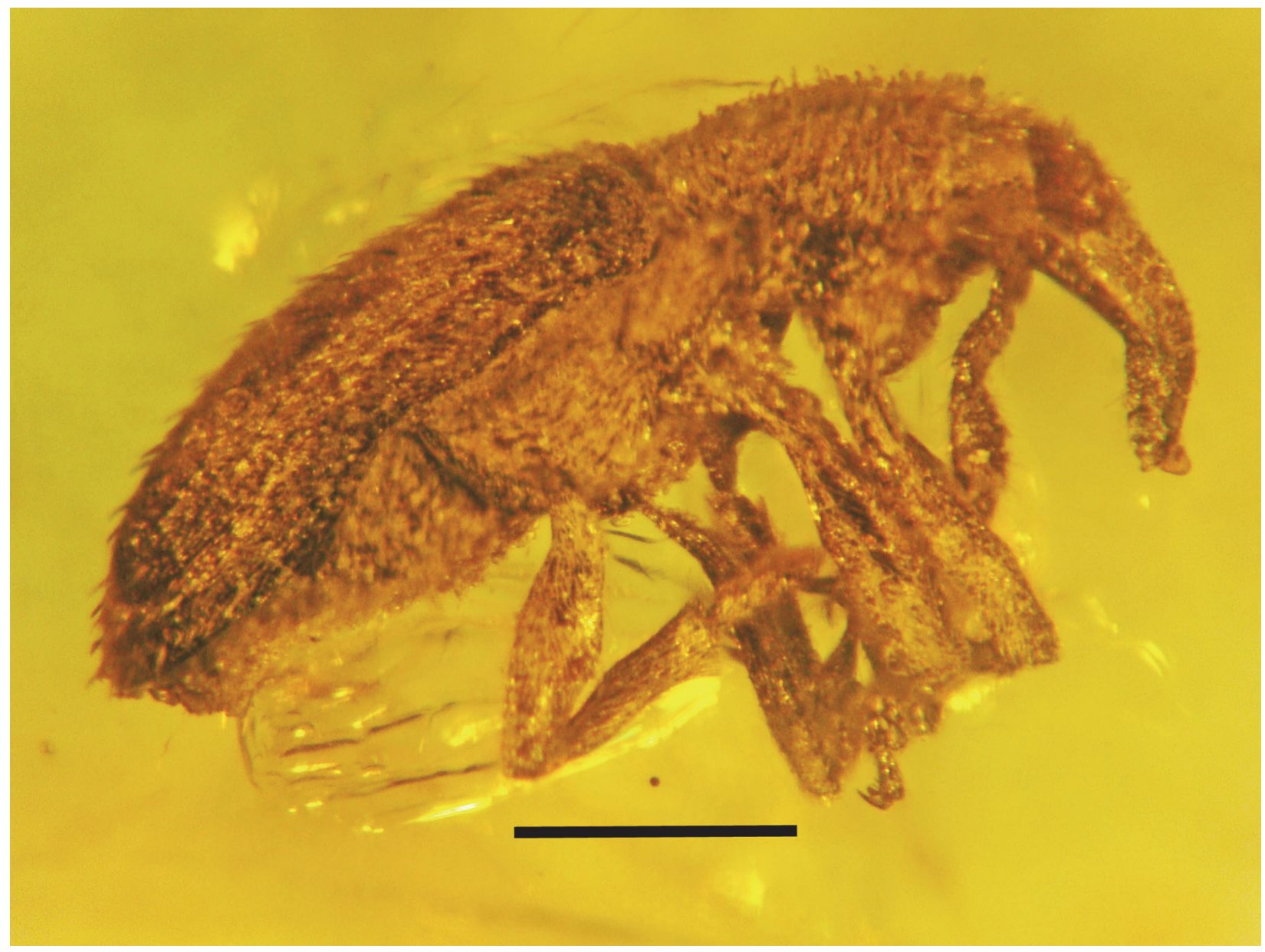

FIGURE 8. Lateral view of Neosibinia lepidosoma sp. nov. in Dominican amber. Bar equals $0.570 \mathrm{~mm}$.

\section{DISCUSSION}

The oldest Curculioninae (Curculio elegans Piton, 1940 and C. havighorstensis Zherikhin, 1995 of the tribe Curculionini) date from the Palaeogene of France and Germany (Piton, 1940; Zherikhin, 1995), with the Burmese Anchineus dolichobothris Poinar and Brown, 2009 transferred to the subfamily Carinae of the family Ithyceridae (Legalov and Poinar, 2015).

The tribe Derelomini sensu Kojima and Morimoto (2005) consists of two genera, or more than 40 genera according to Franz (2006). Most of the species are distributed in the Old World (Alonso-Zarazaga and Lyal, 1999). Three species are recorded from the West Indies and Brazil (O'Brien and Wibmer, 1982; Wibmer and O'Brien, 1986). The Derelomini is represented by only a single species in the West Indies, Derelomus albidus Suffrian, 1872 from Cuba and Puerto Rico. Thus Derelomus thalioculus sp. nov. is the first fossil representative of this genus in Hispaniola. Very little is known about the habits of Derelomus spp. other than the adults are collected from various flowers. Perhaps the best studied members of the tribe are species of Elaeidobius Kuschel, 1952 that are important pollinators of the African oil palm, Elaeis guineensis Jacquin. The larvae develop on the flowers and the adult beetles transfer pollen from plant to plant during their feeding, mating and oviposition activities (Syed et al., 1982). The first reliable description of a Derelomini (Protoceletes wolfschwenningerae Rheinheimer, 2007) is from Eocene Baltic amber (Rheinheimer, 2007).

The tribe Anthonomini, which is abundant in the New World, is represented in Hispaniola by 10 species groups and 19 species in two subgenera (Clark and Burke, 1985, 1986, 1996; Clark, 1987a, 1987b, 1990, 1991a, 1991b, 1991c, 1991d; SotoHernández et al., 2013). Anthonomus cruraluma sp. nov. and $A$. browni sp. nov. are the first members of this genus described from Dominican amber. The subgenus Anthomorphus is not recorded from Hispaniola. Several fossil represen- 


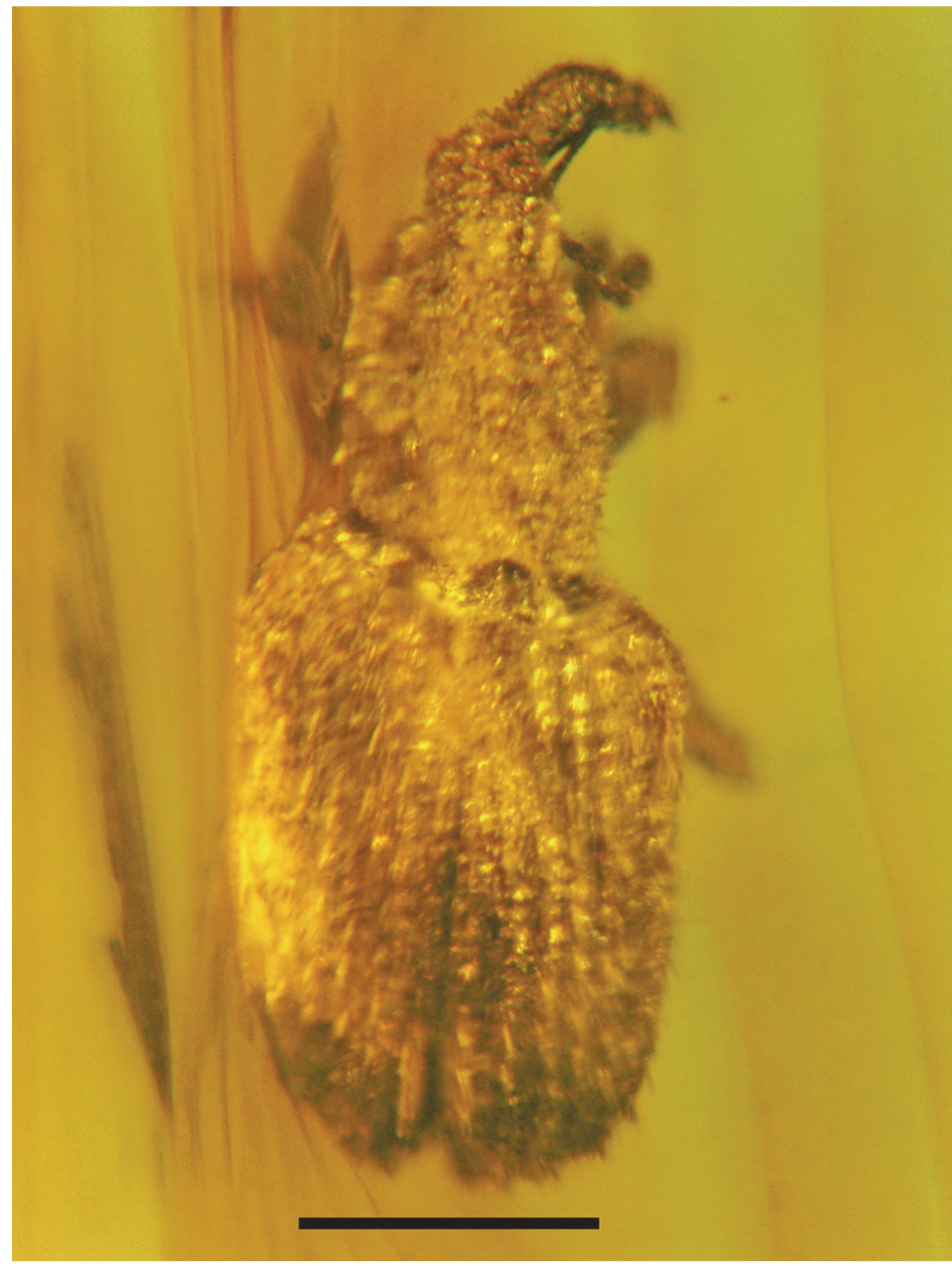

FIGURE 9. Dorsal view of Neosibinia lepidosoma sp. nov. in Dominican amber. Bar equals $0.540 \mathrm{~mm}$.

tatives of the genus Anthonomus Germar, 1817 have been reported (Scudder, 1893, 1900; Wickham, 1912; Cockerell, 1925); however, the transfer of "A." sunchalensis Cockerell, 1925 from the Palaeocene of Argentina and "A." soporus Scudder, 1890 and "A." revictus Scudder, 1893 from the Middle Eocene Green River deposits to the genus Anthonomus is not confirmed. In fact, only A. debilatus Scudder, 1893 from the terminal Eocene of may belong to this genus. A single representative (Anthonomus sp.) of this tribe was previously recorded from Dominican amber (Poinar and Poinar, 1999).
Fossil Tychiini are also known from the Eocene of North America and the Oligocene France, and the Miocene of Germany (Heyden and Heyden, 1866; Oustalet, 1874; Foerster, 1891; Scudder, 1893; Wickham, 1917). Neosibinia lepidosoma gen. et sp. nov. is closely related to the genera Tychius Germar, 1817 and Sibinia Germar, 1817 which comprise the tribe Tychiini. This tribe (sensu Alonso-Zarazaga and Lyal, 1999) is represented by more than 130 species in North America, Central America and the West Indies (O'Brien and Wibmer, 1982). However there are only eight species of extant Tychiini known from the West Indies and only three genera (Lignyodes Dejean, 1835, 
Plocetes LeConte, 1876 and Sibinia) occur in Haiti (O'Brien and Wibmer, 1982; Perez-Gelabert, 2008). The genus Neosibinia has some unique features. Typically, representatives of the tribe have a mucro and uncus, although these structures are missing in some tibiae of a few members of the genus Sibinia (Clark, 1978). The trend toward a reduction of these structures can be observed in various tribes of the subfamily (Zherikhin and Egorov, 1991). Neosibinia is also characterized by separated procoxae, a feature also present in Sibinia sulcifera Clark, 1978. However the rounded elytral apices and covered pygidium in Neosibinia distinguishes it from Sibinia. We propose that Neosibinia is a specialized descendant of Sibinia close to the hispida group.

\section{ACKNOWLEDGEMENTS}

The study was partially supported by the Federal Fundamental Scientific Research Programme for 2013-2020, project no. VI.51.1.7 and the Russian Foundation for Basic Research, project no. 15-04-02971.

\section{REFERENCES}

Alonso-Zarazaga, M.A. and Lyal, C.H.C. 1999. A World Catalogue of Families and Genera Curculionoidea (Insecta: Coleoptera) (Excepting Scolytidae and Platypodidae).Entomopraxis, Barcelona.

Champion, G.C. 1903. Insecta. Coleoptera. Rhynchophora. Curculionidae. Curculioninae (part). Biologia Centrali-Americana, 4:145-312.

Clark, W.E. 1978. The weevil genus Sibinia: natural history, taxonomy, phylogeny, and zoogeography, with revision of the New World species. Quaestiones Entomolgicae, 14:91-387.

Clark, W.E. 1987a. Revision of the unipustulatus group of the weevil genus Anthonomus Germar (Coleoptera: Curculionidae). The Coleopterists Bulletin, 41:73-88.

Clark, W.E. 1987b. The species of Anthonomus in the albolineatus group (Coleoptera: Curculionidae). Transactions of the American Entomological Society, 113:309-359.

Clark, W.E. 1990. Revision of the Anthonomus subgenus Anthonomocyllus Dietz (Coleoptera: Curculionidae). Quaestiones Entomologicae, 26:559-600.

Clark, W.E. 1991a. The Anthonomus guttatus species group (Coleoptera: Curculionidae). Proceedings of the Entomological Society of Washington, 93:262271.

Clark, W.E. 1991b. Revision of the Anthonomus alboannulatus and Anthonomus triensis new species groups (Coleoptera: Curculionidae). The Coleopterists Bulletin, 45:207-226.
Clark, W.E. 1991c. The Anthonomus curvirostris species group (Coleoptera: Curculionidae). Transactions of the American Entomological Society, 117:39-66.

Clark, W.E. 1991d. The Anthonomus rubiginosus species group (Coleoptera: Curculionidae). Transactions of the American Entomological Society, 117:145-166.

Clark, W.E. and Burke, H.R. 1985. Revision of the venustus species group of the weevil genus Anthonomus Germar (Coleoptera: Curculionidae). Transactions of the American Entomological Society, 111:103-170.

Clark, W.E. and Burke, H.R. 1986. Revision of the gularis species group of the genus Anthonomus Germar (Coleoptera: Curculionidae). The Coleopterists Bulletin, 40:1-26.

Clark, W.E. and Burke, H.R. 1987. Revision of the Anthonomus subgenus Anthomorphus Weise (Coleoptera: Curculionidae), Quaestiones Entomologicae, 23:317-364.

Clark, W.E. and Burke, H.R. 1996. The species of Anthonomus Germar (Coleoptera: Curculionidae) associated with plants in the family Solanaceae. Southwestern Entomologist, Supplement, 19:1-114.

Cockerell, T.D.A. 1925. Tertiary insects from Kudia River, Maritime Province, Siberia. Proceedings of the United States National Museum, 68:1-16.

Dejean, P.F.M.A. 1835. Catalogue de la collection de Coléoptères de M. le Baron Dejean. Paris, Méquignon-Marvis, 4:257-360.

Draper, G., Mann, P., and Lewis, J.F. 1994. Hispaniola, p. 129-150. In Donovan, S. and Jackson, T.A. (eds.), Caribbean Geology: An Introduction. The University of the West Indies Publishers' Association, Kingston, Jamaica.

Foerster, B. 1891. Die Insekten des "Plattigen Steinmergels" von Brunstatt. Abhandlungen der Geologischen Specialkarte von Elsass-Lotheringen, 3:333-594.

Franz, N.M. 2006. Towards a phylogenetic system of derelomine flower weevils (Coleoptera: Curculionidae). Systematic Entomology, 31:220-287.

Germar, E.F. 1817. Miscellen und correspondenznachrichten. Magazin der Entomologie, 2:339-341.

Herbst, J.F.W. 1795. Natursystem aller bekannten in- und auslandischen Insekten, als eine Fortsetzung der von Büffonschen Naturgeschichte. Der Kafer. 6. Pauli, Berlin.

Heyden, C. and Heyden, L. 1866. Käfer und Polypen aus der Braunkohle des Siebengebirges. Palaeontographica. Beiträge zur Naturgeschichte der Vorwelt, 15:131-156.

Hustache, A. 1929. Curculionides de la Guadaloupe. Faune des Colonies Françaises, 3:165-267.

Iturralde-Vinent, M.A. and MacPhee, R.D.E. 1996. Age and paleogeographic origin of Dominican amber. Science, 273:1850-1852.

Kojima, H. and Morimoto, K. 2005. Weevils of the tribe Acalyptini (Coleopterai Curculionidae: Curculioninae): redefinition and a taxonomic treatment of the Japanese, Korean and Taiwanese species. Esakia, 45:69-115. 
Kuschel, G. 1952. Los Curculionidae de la Cordillera Chileno-Argentina (1.a parte). Revista Chilena de Entomologia, 2:229-279.

Lacordaire, T. 1866. Histoire Naturelle des Insectes. Genera des Coléoptères ou exposé méthodique et critique de tous les genres proposés jusqu'ici dans cet ordre d'insectes. Vol. 7. Roret, Paris.

LeConte, J.L. 1876. In LeConte, J.L. and Horn, G.H. The Rhynchophora of America north of Mexico. Proceedings of the American Philosophical Society, 15:1-455.

Legalov, A.A. and Poinar, G.O., Jr. 2015. New tribes of the superfamily Curculionoidea (Coleoptera) in Burmese amber. Historical Biology, 27:558-564.

O'Brien, C.W. and Wibmer, G.J. 1982. Annotated checklist of the weevils (Curculionidae sensu lato) of North America, Central America, and the West Indies (Coleoptera: Curculionoidea). Memoirs of the American Entomological Institute, 34:1-383.

Oustalet, M.E. 1874. Recherches sur les insectes fossiles des terraines tertiaires de la France. 2 me partie. Insectes fossiles d'Aix en Provence. Annales des Sciences géologiques de Paris, 5:1-347.

Perez-Gelabert, D.E. 2008. Arthropods of Hispaniola (Dominican Republic and Haiti): a checklist and bibliography. Zootaxa, 1831:1-530.

Piton, L. 1940. Paléontologie du gisement Éocène de Menat (Puy-de-Dôme) (Flore et faune). ClermontFerrand: Imprimeries Paul Vallier.

Poinar, G.O., Jr. 1991. Hymenaea protera sp.n. (Leguminosae: Caesalpinoideae) from Dominican amber has African affinities. Experientia, 47:1075-1082.

Poinar, G.O., Jr. 2009. Dominibrentus leptus, n. gen., n. sp. (Curculionoidea, Brentidae, Cyphagoginae, Dominibrentini, n. tribe), a straight snouted weevil in Dominican amber. Historical Biology, 21:51-55.

Poinar, G.O., Jr. and Brown, A.E. 2009. Anchineus dolichobothris, a new genus and species of Early Cretaceous weevils (Curculionoidea: Coleoptera) in Burmese amber. Proceedings of the Entomological Society of Washington, 111:263-270.

Poinar, G.O., Jr. and Brown, A.E. 2011. Descriptions of a broad-nosed weevil (Eudiagogini: Curculionidae) and false ladybird beetle (Nilionini: Nilionidae) in Dominican amber. Historical Biology, 23:231-235.

Poinar, G.O., Jr. and Legalov, A.A. 2014a. Bicalcasura maculata n. gen., n. sp. (Curculionoidea: Dryopthtoridae) with a list of weevils described from Dominican amber. Historical Biology, 26:449-453.

Poinar, G.O., Jr. and Legalov, A.A. 2014b. New Cryptorhynchinae (Coleoptera: Curculionidae) in Dominican amber. Historical Biology, 26:502-534.

Poinar, G.O., Jr. and Legalov, A.A. 2014c. New species of the subfamily Conoderinae (Coleoptera: Curculionidae) in Dominican amber. Historical Biology, 26:556-562.

Poinar, G.O., Jr. and Legalov, A.A. 2014d. Pleurambus strongylus n. gen., n. sp. (Coleoptera: Belidae) in Dominican amber. Historical Biology, 26:670-674.
Poinar, G.O., Jr. and Legalov, A.A. 2015a. First record of the genus Baris Germar, 1817 (Coleoptera: Curculionidae), in Dominican amber. Fossil Record, 18:3135.

Poinar, G.O., Jr. and Legalov, A.A. 2015b. New Apioninae (Coleoptera: Brentidae) in Dominican amber. Historical Biology, 26:603-607.

Poinar, G.O., Jr. and Legalov, A.A. 2015c. New species of the subfamily Cossoninae (Coleoptera: Curculionidae) in Dominican amber. Historical Biology, 27:491502.

Poinar, G.O., Jr. and Legalov, A.A. 2015d. New species of the genera Dryophthorus Germ. and Stenommatus Woll. (Coleoptera: Dryophthoridae) in Dominican amber. Historical Biology, 27:508-513.

Poinar, G.O., Jr., Legalov, A.A., and Brown, A.E. 2013. Brachycamacina, a new subtribe of the tribe Naupactini (Coleoptera: Curculionidae: Entiminae) in Dominican amber. Palaeontologia Electronica, 16:1-9.

Poinar, G.O., Jr. and Mastalerz, M. 2000. Taphonomy of fossilized resins: determining the biostratinomy of amber. Acta Geologica Hispanica, 35:171-182.

Poinar, G.O., Jr. and Poinar. R. 1999. The Amber Forest. Princeton University Press, Princeton, New Jersey.

Rheinheimer, J. 2007. Neue fossile Rüsselkäfer (Coleoptera: Curculionidae) aus dem Eozän des Baltischen Bernsteins und der Grube Messel bei Darmstadt. Staatliches Museum für Naturkunde, B(365):1-24.

Schlee, D. 1990. Das Bernstein-Kabinett. Begleitheft zur Bernsteinausstellung im Museum am Löwentor, Stuttgart, 28:1-100.

Schoenherr, C.J. 1825. Continuatio Tabulae synopticae Familiae Curculionidum. Isis von Oken, 5:581-588

Scudder, S.H. 1893. Tertiary Rhynchophorus Coleoptera of the United States. Monographs of the United States Geological Survey, 21:1-206.

Scudder, S.H. 1900. Canadian Fossil Insects. 4. Additions to the Coleopterous fauna of the interglacial clays of the Toronto district. Geological Survey of Canada. Contributions to Canadian Palaeontology, 2:67-92.

Soto-Hernández, M.S., Jones, R.W., and Castillo, P.R. 2013. A key to the Mexican and Central America genera of Anthonomini (Curculionidae, Curculioninae). ZooKeys, 260:31-47.

Suffrian, E. 1872. Verzeichniss der von Dr. Gundlach auf der Insel Cuba gesammelten Rüsselkäfer. Archiv für Naturgeschichte, 38:156-207.

Syed, R.A., Law, I.H., and Corley, R.H. 1982. Insect pollination of oil palm: introduction, establishment and pollinating efficiency of Elaeidobius kamerunicus in Malaysia. Planter (Kuala Lumpur), 58: 547-561.

Thomson, C.G. 1859. Skandinaviens Coleoptera, synoptiskt bearbetade. 1. Lund: Lundbergska Boktryckeriet.

Weise, J. 1883. Notizen über Rüsselkäfer. Deutsche Entomologische Zeistchrift, 27:254-256. 
Wibmer, G.J. and O'Brien, C.W. 1986. Annotated checklist of the weevils (Curculionidae, sensu lato) of South America (Coleoptera: Curculionoidea). Memoirs of the American Entomological Institute, 39:i-xvi, 1-563.

Wickham, H.F. 1912. On some fossil Rhynchophorus Coleoptera from Florissant Colorado. Bulletin of the American Museum of Natural History, 31:41-55.
Zherikhin, V.V. 1995. A weevil of the tribe Curculionini (Insecta: Coleoptera, Curculionidae) from the Paleogene of Havighorst, Germamy. Mitteilungen aus dem Geologisch-Paläontologischen Institut der Universität Hamburg, 78:145-148.

Zherikhin, V.V. and Egorov, A.B. 1991. Weevils (Coleoptera, Curculionidae) of the USSR Far East (a review of the subfamilies with description of new taxa). Institute of Biology and Soil science, Vladivostok. [in Russian]. 